\title{
Antimicrobial and Antibiofilm Activities of Methanol Leaf Extract of Citrus maxima against Clinical Isolates of Multidrug Resistant Staphylococcus aureus
}

Sanjeev Kumar ${ }^{1}$, Arup Kumar Samanta ${ }^{2}$, P. Roychoudhury ${ }^{1}$, Honeysmita Das ${ }^{1}$, Kalyan Sarma ${ }^{3}$, Richa Sarkar', Fatema Akter', P.K. Subudhi', T.K. Dutta ${ }^{1}$

10.18805/IJAR.B-4559

\begin{abstract}
Background: Mitigation process to curb the ever increasing problem of antimicrobial resistance through development of new class of antimicrobials is slow and costly affairs. Research on alternative to conventional antimicrobials using plant based products as good source of numerous phytochemicals have potential to cope up the antimicrobial resistance. The present study was formulated on detection of in vitro antimicrobial and antibiofilm properties of methanol leaf extract of Citrus maxima against clinical isolates of Staphylococcus aureus.

Methods: Leaves of Citrus maxima plants were collected from the campus of College of Veterinary Sciences and Animal Husbandry, Central Agricultural University, Aizawl, Mizoram and processed for preparation of methanol crude extract. The plant extracts were evaluated for their phytochemical and antioxidant properties using DPPH (2, 2-Diphenyl-1-picrylhydrazyl) method. Twenty well characterized biofilm producing and multidrug resistant Staphylococcus aureus strains recovered from milk of mastitic cows from Mizoram were received from the cultural repository of the department. The plant extracts were subjected to determine their antimicrobial and antibiofilm activities against all the bacterial isolates including S. aureus (ATCC 29213) by in vitro agar well diffusion method and 96 well microtiter plate methods, respectively. The MIC value of the plant extracts were determined by microdilution method.

Result: In the methanol leaf extract of $C$. maxima alkaloids, glycosides, terpenoids, tannin and phenol and flavonoids were detected by qualitative analysis. Saponin, protein, free amino acids, steroids and carbohydrates were not detected. The free radical scavenging potential of the extract was found to be $10.66 \pm 1.84 \%$ to $36.10 \pm 1.98 \%$, which was comparatively lower than ascorbic acid $(83.39 \pm 0.13 \%$ to $89.76 \pm 0.24 \%)$. A total of $8(40.0 \%), 5(25.0 \%)$ and $7(35.0 \%)$ strains were recorded as weak, moderate and strong biofilm producer. Maximum antibacterial activity against standard culture was observed with the zone of inhibition of $18 \mathrm{~mm}$ at $200 \mathrm{mg} / \mathrm{mL}$ concentration and MIC value at $25 \mathrm{mg} / \mathrm{mL}$. Maximum antimicrobial activities against clinical isolates were recorded with $11.8 \pm 1.13 \mathrm{~mm}$ zone of inhibition at $200 \mathrm{mg} / \mathrm{mL}$ and MIC value at $25 \mathrm{mg} / \mathrm{mL}$. The clinical isolates exhibited highest (85.94 $\pm 1.00 \%)$ biofilm inhibition at 6.25 $\mathrm{mg} / \mathrm{mL}$. To the best of our knowledge, this is the first-ever report on antibiofilm and antioxidative activities of $C$. maxima leaf extracts against any bacteria.
\end{abstract}

Key words: Antibiofilm, Antimicrobial, Citrus maxima, Leaves, Staphylococcus aureus.

\section{INTRODUCTION}

Development and spread of multidrug-resistant (MDR) as well as extremely drug-resistant bacteria in the environment are posing a serious threat to public health globally (Basak et al., 2016). The World Health Organization, in a report, estimated that 10 million people may die annually due to antimicrobial resistance (AMR) by 2050 if no measures be taken (de Kraker et al., 2016). The development of new classes of antibiotics is very slow and not affordable for most of the population to combat the issue of AMR. Biofilm plays a very important role in the development of AMR as it prevents the entry of drugs inside the bacterial cytoplasm. Also inside the biofilm, the rate of mutation and transfer of resistance genes is very high between the bacteria (Banerjee et al., 2019). Bacteria with biofilm exhibit the AMR a few folds higher than the planktonic state.

India is rich with its plant biodiversity including medicinal plants (Samal, 2016). Mizoram, the land lock state of North eastern region of India is the home of more than 400 species
${ }^{1}$ Department of Veterinary Microbiology, Central Agricultural University-Imphal, Selesih-796 015, Aizawl, Mizoram, India.

${ }^{2}$ Department of Animal Nutrition, Central Agricultural UniversityImphal, Selesih-796 015, Aizawl, Mizoram, India.

${ }^{3}$ Department of Veterinary Medicine, Central Agricultural UniversityImphal, Selesih-796 015, Aizawl, Mizoram, India.

Corresponding Author: T.K. Dutta, Department of Veterinary Microbiology, College of Veterinary Sciences and Animal Husbandry, Central Agricultural University, Selesih- 796 015, Aizawl, Mizoram, India. Email: tapandutta@rediffmail.com

How to cite this article: Kumar, S., Samanta, A.K., Roychoudhury, P., Das, H., Sarma, K., Sarkar, R., Akter, F., Subudhi, P.K. and Dutta, T.K. (2021). Antimicrobial and Antibiofilm Activities of Methanol Leaf Extract of Citrus maxima against Clinical Isolates of Multidrug Resistant Staphylococcus aureus. Indian Journal of Animal Research. DOI: 10.18805/IJAR.B-4559.

Submitted: 04-06-2021 Accepted: 26-07-2021 Online: 21-08-2021 
Antimicrobial and Antibiofilm Activities of Methanol Leaf Extract of Citrus maxima against Clinical Isolates of Multidrug...

of medicinal plants (Rai and Lalramnghinglova, 2010). The use of medicinal plants is inculcated in the culture of tribal people of North East India including Mizoram (Debbarma et al., 2017). Citrus maxima is a perennial plant commonly known as Pomelo or Nobab or Chakotra or Shaddock. Different parts of these plants including leaves, fruit peel and pulp are known for their antibacterial activities against significantly pathogenic bacterial strains including Staphylococcus aureus and Escherichia coli, antitumor, antihypertension and antidiabetic activities (Singh and Navneet, 2017). They are also a rich source of vitamin C and antioxidants (Ani and Abel, 2018).

The present study was conducted to explore the antimicrobial and antibiofilm activity of methanol leaf extract of Citrus maxima against clinical isolates of Staphylococcus aureus.

\section{MATERIALS AND METHODS} Place of work

The entire work was carried out in the Department of Veterinary Microbiology, College of Veterinary Sciences and Animal Husbandry, Central Agricultural University, Selesih, Aizawal, Mizoram during April 2020 to February, 2021.

\section{Preparation of plant crude extracts}

The leaves of Citrus maxima were collected from the campus of College Veterinary Sciences and Animal Husbandry, Central Agricultural University, Selesih, Aizawl, Mizoram, India. The plants were identified by Dr. Lalfakzuala, Associate Professor, Department of Botany, Mizoram University, Aizawl, Mizoram.

Collected leaves were washed with tap water followed by rinsing with distilled water and dried under shade for 7 days. The extracts were prepared as per the method described by Obeidat et al. (2012). In brief, the dried leaves were turned into power with the electric grinder. Twenty grams of powdered leaves were soaked in $200 \mathrm{~mL}$ methanol (1:10) for $24 \mathrm{~h}$ at room temperature with shaking at an interval of two hours. After soaking,the crude extract was filtered through Whatman filter paper No. 1 and the filtrate was concentrated in a rotary evaporator at $40^{\circ} \mathrm{C}$ under vacuum. The concentrated extract was re-suspended in methanol $(99.80 \%)$ to prepare the stock @200 mg/mL and stored at $-20^{\circ} \mathrm{C}$ after filtration through a membrane filter $(0.45 \mu \mathrm{m})$.

\section{Phytochemical analysis of methanol crude extract of Citrus maxima leaves}

The preliminary screening for the qualitative analysis of phytochemicals of the extract was performed for alkaloids, steroids, glycosides, flavonoids, terpenoids, saponin, tannin, phenol, free amino acids, protein and carbohydrate as per the method described by Joanne Susanti et al. (2007).

\section{Bacterial cultures}

Twenty (20) Staphylococcus aureus strains isolated from milk samples of mastitic cows of Aizawl, Mizoram were received from the bacterial repository of the Department of Veterinary Microbiology, College of Veterinary Sciences and Animal Husbandry, Central Agricultural University, Aizawl, Mizoram. All the bacteria were characterized by standard bacteriological techniques as described by Ewing (1986) and further confirmed by BD Phoenix automated bacterial identification system. S. aureus (ATCC 29213) was used as control organism under the study. All the pure bacterial isolates were stored at $-80^{\circ} \mathrm{C}$ in glycerol $(25 \% \mathrm{~V} / \mathrm{V})$ for further use. All the bacterial isolates were biofilm producer and resistant to minimum 3 classes of antimicrobial agents, hence multidrug resistant (Chakraborty, 2017; Das et al., 2015).

\section{Determination of biofilm production ability of the Staphylococcus aureus isolates}

All the isolates were subjected to 96 wells microtiter plate assay as described by Cihan et al. (2017) for determination of biofilm production ability. Bacterial biofilms were classified based on an OD cut-off ODc (OD of negative control). The $O D c$ was defined as three standard deviations from the $O D$ mean of the negative control. No biofilm formation was OD $<O D c$; a weak biofilm former was ODc $<O D<(2 X O D c)$; a moderate was biofilm former $(2 \mathrm{X} \mathrm{ODc})<\mathrm{OD}<(4 \mathrm{X} \mathrm{ODc})$; and a strong biofilm former was $(4 X \mathrm{ODc})<\mathrm{OD}$.

\section{Antimicrobial activity of methanol crude extract of Citrus maxima leaves}

The antimicrobial activity of the plant extracts was done by agar well diffusion method in Muller Hinton agar (HiMedia, Mumbai) as described by Lahlah et al. (2012). All the bacteria were grown on nutrient agar medium (HiMedia, Mumbai) and 2-3 pure colonies were picked up from the culture plate and transferred to the Luria Bertani (LB) broth. The tube was incubated for $4-5 \mathrm{hrs}$ at $37^{\circ} \mathrm{C}$ and the inoculum density was standardized at $0.5 \mathrm{McF}$ arland. The inoculums were inoculated over the MHA plate using absorbent cotton swab so that a lawn culture may grow. The stock crude extract $(200 \mathrm{mg} / \mathrm{mL})$ was diluted @ 200, 100, 50, 25, 12.5, 6.25 and $3.125 \mathrm{mg} / \mathrm{mL}$ in methanol. A total of $100 \mu \mathrm{L}$ of extract was loaded in each well and incubated at $37^{\circ} \mathrm{C}$ for $24 \mathrm{hr}$. Diameters of zone of inhibition were measured by scale. Penicillin-G (10 IU, HiMedia, Mumbai) and methanol were used as a positive and negative control, respectively and S. aureus (ATCC 25923) were used as control organism.

Determination of minimum inhibitory concentration (MIC) of methanol leaf extract of Citrus maxima

MIC of the plant extracts were determined in 96 well plate following the method described by Mazzola et al. (2009), where 2,3,5 triphenyl tetrazolium chloride (TTC) was used as chromogenic agent. One hundred $\mu \mathrm{L}$ of LB broth was dispensed in each well of the 96 wells plate followed by 100 $\mu \mathrm{L}(20 \mathrm{mg})$ of each extracts added in the first well followed by serial two fold dilution of the plant extracts. Finally $50 \mu \mathrm{L}$ of bacterial suspension (adjusted to $0.5 \mathrm{McF}$ arland standard) were added to each well. Plates were covered and incubated 
at $37^{\circ} \mathrm{C}$ for $24 \mathrm{~h}$. After incubation, $20 \mu \mathrm{L}$ of $0.1 \%$ TTC were added to each well and incubated for 15 minutes. The MIC value was determined based upon the red coloration of the liquid in each wells.

\section{Antibiofilm activity of methanol leaf extract of Citrus maxima}

The antibiofilm effect of the plant extracts was determined by tissue culture plate method (Sánchez et al., 2016). Overnight grown culture of bacteria (0.4 OD) was centrifuged at $7000 \mathrm{rpm}$ for $10 \mathrm{~min}$ at $4^{\circ} \mathrm{C}$. The cell pellet was washed twice with phosphate buffered solution (PBS) followed by centrifugation at $7000 \mathrm{rpm}$ for $10 \mathrm{~min}$ at $4^{\circ} \mathrm{C}$. Finally, the pellet was re-suspended in PBS and OD value was checked at $600 \mathrm{~nm}(0.4 \mathrm{OD})$ in spectrophotometer. A serial two fold dilution of the plant extracts was made followed by addition of $10 \mu \mathrm{L}$ of $0.4 \mathrm{OD}$ bacterial cultures in each wells and incubated at $37^{\circ} \mathrm{C}$ for $18-24$ hours. Additional LB broth was added to make the final volume up to $200 \mu \mathrm{L}$ in each wells and incubated at $37^{\circ} \mathrm{C}$ for $24 \mathrm{hrs}$. After incubation the wells were washed twice with PBS $(\mathrm{pH} 7.4)$ to remove free floating planktonic bacteria. Then $200 \mu \mathrm{L}$ of $0.1 \%$ crystal violet solution was added in each well followed by incubation at $37^{\circ} \mathrm{C}$ for $30 \mathrm{~min}$ to stain the adhered cells. The wells were washed twice with $200 \mu \mathrm{L}$ PBS ( $\mathrm{pH} \mathrm{7.4)}$ to remove excess stain and the plates were air dried. Then $200 \mu \mathrm{L}$ methanol was added in each wells to solubilize the bound crystal violet. The untreated wells were used as control (uninoculated broth and bacteria).

The OD value at $570 \mathrm{~nm}$ was recorded to check the result using the following formula:

$$
\% \text { Biofilm inhibition }=\frac{\text { OD control }- \text { OD test }}{\text { OD control }} \times 100
$$

Where,

OD control is the absorbance of untreated control and OD test is the absorbance of treated.

\section{Antioxidant properties of methanol crude extract of Citrus maxima leaves}

The antioxidant activity was measured as a free radical scavenging activity by using DPPH (2, 2-Diphenyl-1picrylhydrazyl) as described elsewhere (Pulipati et al., 2017). Briefly, dried crude extracts were dissolved in methanol to prepare different concentrations ranging from $100-500 \mu \mathrm{g} /$ $\mathrm{mL}$. Then, $1 \mathrm{~mL}$ of each concentration was mixed with $3 \mathrm{~mL}$ of $0.35 \mathrm{mM} \mathrm{DPPH}$ in a test tube and was incubated in the dark room at room temperature for $1 \mathrm{hr}$. After incubation, the absorbance was measured at $517 \mathrm{~nm}$ using a spectrophotometer
(MULTISKAN GO, Thermo Scientific). For control, $1 \mathrm{~mL}$ of methanol was mixed with $3 \mathrm{~mL}$ of $0.35 \mathrm{mM} \mathrm{DPPH}$ in a test tube. For reference, ascorbic acid was used @ 100 - 500 $\mu \mathrm{g} / \mathrm{mL}$. The antioxidant activity was measured in triplicates. The following formula was used to determine the DPPH radical scavenging activity of methanol extract of $C$. maxima leaves:

$\%$ inhibition of DPPH radical =

$$
\left(A_{\text {control }}-A_{\text {standard or sample }}\right) / A_{\text {control }} \times 100
$$

\section{RESULTS AND DISCUSSION}

The development of multidrug-resistant (MDR) and extensive drug-resistant (EDR) bacteria all around the world has created a dire need for the development and exploration of new antimicrobial agents and/or new alternative approaches. In recent years, plant-based products are prioritized to explore the potential antimicrobial compounds to treat the MDR and EDR bacteria. Recent studies showed that plants have the potential to tackle the menace of antimicrobial resistance. Plants are a rich source of phytochemicals (alkaloids, saponins, tannins, non-tannin phenols, flavonoids, steroids, etc.) and are reported to have antimicrobial and antibiofilm properties (Nethathe and Ndip, $2011)$. In the present study, a total of $3 \mathrm{~g}(18.45 \%)$ of methanolic crude extract was recovered from $20 \mathrm{~g}$ of Citrus maxima leaves powder and used for further study. In phytochemical analysis, the methanol leaf extract of $C$. maxima was found to be positive for alkaloids, glycosides, terpenoids, tannin and phenol and flavonoids, whereas saponin, protein, free amino acids, steroids and carbohydrates remained absent. Sapkota et al. (2020) also mentioned the presence of similar phytochemicals in the ethanol extract of $C$. maxima leaves. Similarly, Showmiya and Ananthi (2018) also reported the availability of alkaloids, amino acids, carotenoids, carbohydrates, coumarins, flavonoids, sesquiterpene and steroids in ethanol extract of C. maxima leaves.

The methanol leaf extract of $C$. maxima was found to be a very good antibacterial agent in vitro against the standard culture of $S$. aureus (ATCC 29213) with a diameter of zones of inhibition of $18 \mathrm{~mm}, 15 \mathrm{~mm}, 14 \mathrm{~mm}, 12 \mathrm{~mm}$ and $11 \mathrm{~mm}$ against $200 \mathrm{mg} / \mathrm{mL}, 100 \mathrm{mg} / \mathrm{mL}, 50 \mathrm{mg} / \mathrm{mL}, 25 \mathrm{mg} /$ $\mathrm{mL}$ and $12.5 \mathrm{mg} / \mathrm{mL}$ of the crude extract, respectively (Table 2 , Fig 1). The MIC value of the same extract against $S$. aureus (ATCC 29213) was found to be $25 \mathrm{mg} / \mathrm{mL}$. In the case of the clinical isolates, antimicrobial activity of methanol leaf extract of $C$. maxima was varied at $11.8 \pm 1.13 \mathrm{~mm}, 8.9 \pm 1.03$ $\mathrm{mm}, 6.65 \pm 2.49 \mathrm{~mm}$ and $5.95 \pm 2.15 \mathrm{~mm}$ of zone of inhibition

Table 1: The per cent inhibition of DPPH radicals by different extracts of plants.

\begin{tabular}{lccccc}
\hline \multirow{2}{*}{ Extract } & \multicolumn{4}{c}{ \% Inhibition of DPPH radical by different concentration of plant extracts } \\
\cline { 2 - 6 } & $100 \mu \mathrm{g} / \mathrm{mL}$ & $200 \mu \mathrm{g} / \mathrm{mL}$ & $300 \mu \mathrm{g} / \mathrm{mL}$ & $400 \mu \mathrm{g} / \mathrm{mL}$ & $500 \mu \mathrm{g} / \mathrm{mL}$ \\
\hline Leaves & $10.66 \pm 1.84$ & $21.95 \pm 1.34$ & $25.39 \pm 1.05$ & $33.54 \pm 0.66$ & $36.10 \pm 1.98$ \\
Ascorbic acid $^{* *}$ & $83.39 \pm 0.13$ & $85.63 \pm 0.60$ & $86.37 \pm 0.30$ & $87.94 \pm 0.14$ & $89.76 \pm 0.24$ \\
\hline
\end{tabular}

\footnotetext{
${ }^{* *}$ Ascorbic acid was used as reference compound.
} 
Antimicrobial and Antibiofilm Activities of Methanol Leaf Extract of Citrus maxima against Clinical Isolates of Multidrug...

Table 2: Antibacterial activity of methanol leaf extract of Citrus maxima at different concentration against Staphylococcus aureus.

\begin{tabular}{lcccccc}
\hline & \multicolumn{5}{c}{ Zone of inhibition (in $\mathrm{mm})$} \\
\cline { 2 - 7 } Bacteria & 200 & 100 & 50 & 25 & 12.5 & 6.25 \\
\hline ATCC 29213 & 18 & 15 & 14 & 12 & 11 & - \\
Clinical isolates $(\mathrm{n}=20)$ & $11.8 \pm 1.13$ & $8.9 \pm 1.03$ & $6.65 \pm 2.49$ & $5.95 \pm 2.15$ & - & - \\
\hline
\end{tabular}

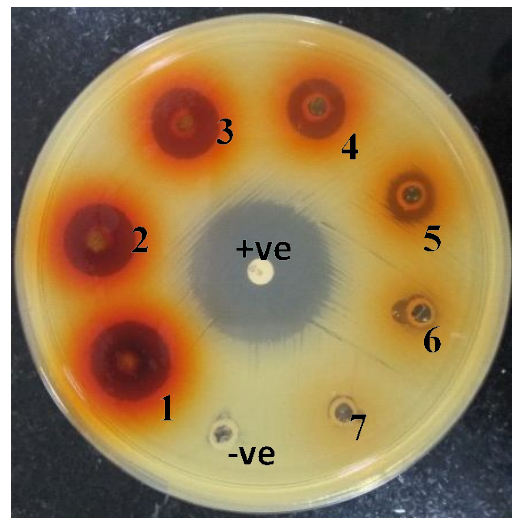

Fig 1: Antibacterial susceptibility test of methanol leaf extract of Citrus maxima by well diffusion method. Well No. 1-7 contains $200 \mathrm{mg} / \mathrm{mL}, 100 \mathrm{mg} / \mathrm{mL}, 50 \mathrm{mg} / \mathrm{mL}, 25 \mathrm{mg} / \mathrm{mL}, 12.5 \mathrm{mg} / \mathrm{mL}$,

$6.25 \mathrm{mg} / \mathrm{mL}$ and $3.125 \mathrm{mg} / \mathrm{mL}$ crude extract, respectively.

Penicillin G (10 IU) and methanol were used as positive and negative control, respectively.

at the concentration of $200 \mathrm{mg} / \mathrm{mL}, 100 \mathrm{mg} / \mathrm{mL}, 50 \mathrm{mg} / \mathrm{mL}$ and $25 \mathrm{mg} / \mathrm{mL}$, respectively. For all the isolates, the MIC value was recorded at $25 \mathrm{mg} / \mathrm{mL}$. In an earlier study, the antimicrobial activity of methanol leaf extracts of $C$. maxima was recorded with $11.5 \mathrm{~mm}$ zone of inhibition at a concentration of $100 \mathrm{mg} / \mathrm{mL}$ against $S$. aureus (MTCC 3215) with the MIC value of $12.5 \mathrm{mg} / \mathrm{mL}$ (Abirami et al., 2013). In another study from Odisha, India the antimicrobial activity of methanol leaf extract of $C$. maxima was recorded with a zone of inhibition of $21.82+0.44 \mathrm{~mm}$ at a concentration of 1 $\mathrm{mg} / \mathrm{mL}$ and the MIC value was $30 \mathrm{mg} / \mathrm{mL}$ against $S$. aureus (MTCC 9886) (Prusty and Patro, 2014). The antimicrobial activity of methanolic leaf extract of $C$. maxima might be due to the presence of alkaloids, phenolics, tannins, flavonoids and steroids, which are known to be good antimicrobial agents (Nethathe and Ndip, 2011).

In the present study, strong biofilm production ability was exhibited by S. aureus (ATCC 29213). Among the clinical isolates $8(40.0 \%), 5(25.0 \%)$ and $7(35.0 \%)$ strains were recorded as weak, moderate and strong biofilm producer. All the isolates were subjected to treatment with the plant extracts to determine their antibiofilm properties. As depicted in Table 3, the methanol leaf extract of C. maxima also exhibited an encouraging level $(81 \%)$ of biofilm inhibition activity against $S$. aureus (ATCC 29213) at a concentration of $3.125 \mathrm{mg} / \mathrm{mL}$. Whereas, the clinical isolates exhibited percent inhibition ranging from $19.21 \pm 1.22 \%$ to $85.94 \pm 1.00 \%$ at the concentration of $100 \mathrm{mg} / \mathrm{mL}$ and $6.25 \mathrm{mg} / \mathrm{mL}$, respectively. The inhibition capability of the extracts was in increasing order with the increased dilution and reached at highest at the concentration at $3.125 \mathrm{mg} / \mathrm{mL}$ (Table 2), which might be due to the improved capacity of penetration of the molecules at lower concentration through the biofilm substances. Beyond $3.125 \mathrm{mg} / \mathrm{mL}$ concentration, the amount of active molecules was not at the threshold level to inhibit the biofilms. To the best of our knowledge, no reports are available on antibiofilm activity of crude extract of $C$. maxima leaves. In another study from the same laboratory, we have reported the antibiofilm activity of crude extract of Melastoma malabathricum against E. coli and S. aureus (Das et al., 2021). Although the active principles of the crude extracts of C. maxima leaves were not purified and analyzed independently for their antibiofilm activity, it is assumed that it may be due to the alkaloids, polyphenols and terpenoids present in the extracts. An alkaloid, viz., berberine was found to be a very good biofilm inhibitor against $F$. nucleatum (MIC at $31.25 \mu \mathrm{g} / \mathrm{mL}$ ), P. intermedia (MIC at $3.8 \mathrm{mg} / \mathrm{mL}$ ) and $E$. faecalis (MIC at $0.5 \mathrm{mg} / \mathrm{mL}$ ). Reserpine, another alkaloid was also exhibited significant antibiofilm property against K. pneumoniae at $0.0156 \mathrm{mg} / \mathrm{mL}$ (Skogman et al., 2012). The ethanolic leaf extract of Pandanus amaryllifolius Roxb (Pandanaceae) was reported to be a potent antibiofilm agent due to the presence of alkaloids (Tsai et al., 2015) and polyphenols of cranberries were also exhibited very good antibiofilm activity (Koo et al., 2006). The polyphenol-rich methanol extract of Chilean propolis could able to prevent $50 \%$ biofilm formation by $S$. aureus, $P$. aeruginosa and $E$. coli at a concentration of $0.2 \mu \mathrm{g} / \mathrm{mL}$. Three terpenoid compounds, viz., techtochrysin, negletein and quercitin-3glucoside isolated from the leaves of Scutellaria oblonga was found to be good antibiofilm agent against $B$. subtilis, S. aureus and E. coli (Rajendran et al., 2016). Terpenoid and flavonolignans from the seeds of Silymum marianum were also could inhibit biofilm formation against $S$. aureus (Vimberg et al., 2015).

In the present study, it was observed that the methanolic crude extract of $C$. maxima leaves have significant antioxidant property. The antioxidant property was measured as the free radical scavenging potential of this extract by the DPPH method. The free radical scavenging potential of the extract was found to be $10.66 \pm 1.84 \%$ to $36.10 \pm 1.98 \%$, which was comparatively lower than ascorbic acid (83.39 \pm $0.13 \%$ to $89.76 \pm 0.24 \%$ ) (Table 1 ). Although no data on antioxidant activity of methanol leaves extract of $C$. maxima are available but similar activities were recorded in the aqueous (Feksa et al., 2018), hexane and ethyl acetate (Fidrianny et al., 2016) leaves extract of the same plant by 
Antimicrobial and Antibiofilm Activities of Methanol Leaf Extract of Citrus maxima against Clinical Isolates of Multidrug...

Table 3: Antibiofilm activity of methanol extract of Citrus maxima leaves at different concentration of plant extract against Staphylococcus aureus.

\begin{tabular}{|c|c|c|c|c|c|c|c|c|c|c|}
\hline \multirow{3}{*}{ Bacteria } & \multicolumn{10}{|c|}{ Per cent inhibition of biofilm formation } \\
\hline & \multicolumn{10}{|c|}{ Plant extract concentration (in $\mathrm{mg} / \mathrm{mL}$ ) } \\
\hline & $\begin{array}{c}100 \\
\mathrm{mg} / \mathrm{mL}\end{array}$ & $\begin{array}{c}50 \\
\mathrm{mg} / \mathrm{mL}\end{array}$ & $\begin{array}{c}25 \\
\mathrm{mg} / \mathrm{mL}\end{array}$ & $\begin{array}{c}12.5 \\
\mathrm{mg} / \mathrm{mL}\end{array}$ & $\begin{array}{c}6.25 \\
\mathrm{mg} / \mathrm{mL}\end{array}$ & $\begin{array}{c}3.125 \\
\mathrm{mg} / \mathrm{mL}\end{array}$ & $\begin{array}{c}1.56 \\
\mathrm{mg} / \mathrm{mL}\end{array}$ & $\begin{array}{c}0.78 \\
\mathrm{mg} / \mathrm{mL}\end{array}$ & $\begin{array}{c}0.39 \\
\mathrm{mg} / \mathrm{mL}\end{array}$ & $\begin{array}{r}0.195 \\
\mathrm{mg} / \mathrm{mL}\end{array}$ \\
\hline ATCC 29213 & 51 & 49 & 42 & 72 & 75 & 81 & 59 & 53 & 48 & 49 \\
\hline $\begin{array}{l}\text { Clinical } \\
\text { isolates }(n=20)\end{array}$ & $\begin{array}{l}19.21 \\
\pm 1.22\end{array}$ & $\begin{array}{r}12.04 \\
\pm 2.93\end{array}$ & $\begin{array}{r}27.32 \\
\pm 8.77\end{array}$ & $\begin{array}{c}76 \\
\pm 1.87\end{array}$ & $\begin{array}{r}85.94 \\
\pm 1.00\end{array}$ & $\begin{array}{r}85.23 \\
\pm 0.12\end{array}$ & $\begin{array}{r}71.63 \\
\pm 0.25\end{array}$ & $\begin{array}{r}70.49 \\
\pm 0.46\end{array}$ & $\begin{array}{r}69.80 \\
\pm 0.29\end{array}$ & $\begin{array}{r}68.12 \\
\pm 0.63\end{array}$ \\
\hline
\end{tabular}

DPPH method. Free radicals are one of the important and integral parts of the host immune system and help in eliminating the pathogenic agent, particularly in the respiratory burst mechanism adopted by phagocytic cells. These free radicals are used to kill the pathogenic agent as well as damage the host cells and other cellular structures due to oxidative stress (Marri and Richner, 2015). The antioxidant property of the extract can provide additional benefits to the patient by reducing oxidative stress/damage during treatment. The antioxidant property of the plant extract under the present study might be due to the presence of flavonoids, which are reported to be a potent antioxidant and anti-inflammatory agents (Gutiérrez-Grijalva et al., 2018).Similarly, the phenolics of the aqueous, methanol and acetone extracts of Hydnora africana root are also reported to have antioxidant activity besides their antimicrobial and anti-inflammatory activities (Wintola and Afolayan, 2015).

\section{CONCLUSION}

Methanol leaf extract of Citrus maxima exhibited encouraging antimicrobial, antibiofilm and antioxidant properties against $S$. aureus by in vitro techniques. This is the first-ever report on antibiofilm and antioxidative activities of $C$. maxima leaf extracts against any bacteria. With the observations of the present study, it may be postulated that the extracts in their purified form may be used as topical antimicrobial preparation against biofilm-producing $S$. aureus and other bacterial agents. Further studies are under progress to observe the activities against other bacterial pathogens.

\section{ACKNOWLEDGEMENT}

The authors thank the Dean of College of Veterinary Sciences and Animal Husbandry, Selesih, Aizawl, Mizoram for their timely help and DBT project No. BT/PR16149/NER/ 95/85/2015 dated 19/01/2017 and BT/HRD/11/017/2020 dated $04 / 08 / 2020$ for financial support to complete this study.

\section{REFERENCES}

Abirami, A., Nagarani, G. and Siddhuraju, P. (2013). Antimicrobial activity of crude extract of Citrus hystrix and Citrus maxima. International Journal of Pharmaceutical Science and Research. 4: 1-5.

Ani, P.N. and Abel, H.C. (2018). Nutrient, phytochemical and antinutrient composition of Citrus maxima fruit juice and peel extract. Food Science and Nutrition. 6(3): 653-658.
Banerjee, D., Shivapriya, P.M., Gautam, P.K., Misra, K., Sahoo, A.K. and Samanta, S.K. (2019). A review on basic biology of bacterial biofilm infections and their treatments by nanotechnology-based approaches. Proceedings of the National Academy of Sciences, India Section B: Biological Sciences, pp. 1-7.

Basak, S., Singh, P. and Rajurkar M. (2016). Multidrug resistant and extensively drug resistant bacteria: A study. Journal of Pathogens. 2016: e4065603.

Chakraborty, S. (2017). Studies on antimicrobial resistance and biofilm producing properties of Escherichia coli, Salmonella spp., Staphylococcus aureus and Pseudomonas aeruginosa isolated from cattle, pig and poultry of Mizoram, India. MVSc thesis. Submitted to the Central Agricultural University, Lamphelpet, Imphal, Manipur.

Cihan, A.C., Karaca, B., Ozel, B.P. and Kilic, T. (2017). Determination of the biofilm production capacities and characteristics of members belonging to Bacillaceae family. World Journal of Microbiology and Biotechnology. 33(6): 118.

Das, G., Lalnunpuia, C., Sarma, K., Behera, S.K., Dutta, T.K., Bandyopadhyay, S. (2015). Prevalence of Staphylococcus aureus associated sub-clinical mastitis in crossbred cows in Mizoram. Ruminant Science. 4(2): 167-170.

Das, H., Samanta, A.K., Kumar, S., Roychoudhury, P., Sarma, K., Akter, F., Subudhi, P.K. and Dutta, T.K. (2021). In vitro antimicrobial, antibiofilm and antiquorum Sensing activity of Indian Rhododendron (Melastoma malabathricum) against Clinical Isolates of Escherichia coli and Staphy-lococcus aureus. Indian Journal of Animal Research. DOI: $10.18805 /$ IJAR.B-4415.

Debbarma, M., Pala, N.A., Kumar, M. and Bussmann, R.W. (2017). Traditional knowledge of medicinal plants in tribes of Tripura in northeast, India. African Journal of Traditional, Complementary and Alternative Medicines. 14(4): 156-168.

deKraker, M.E., Stewardson, A.J. and Harbarth, S. (2016). Will 10 million people die a year due to antimicrobial resistance by 2050? PLoS Medicine. 13(11): e1002184.

Ewing, W.H. (1986). Edward and Ewing's Identification of Enterobacteriaceae, $4^{\text {th }}$ edn. New York Elsevier: 1-536.

Feksa, D.L., Coelho, R.P., da Costa Güllich, A.A., Dal Ponte, E.S., Piccoli, J.D. and Manfredini, V. (2018). Extract of Citrus maxima (pummelo) leaves improve hepatoprotective activity in Wistar rats submitted to the induction of non-alcoholic hepatic steatosis. Biomedicine and Pharmacotherapy. 98: 338-346.

Fidrianny, I.R., Sari, E.L., Ruslan, K.O. (2016). Phytochemical content and antioxidant activities in different organs of pomelo [Citrus maxima [BURM.] merr.] using 2, 2DiphenyL-1-Picrylhydrazyl and phosphomolyb-denum assays. Asian Journal Pharmaceutical and Clinical Research. 9: 185-190. 
Gutiérrez-Grijalva, E.P., Picos-Salas, M.A., Leyva-López, N., CriolloMendoza, M.S., Vazquez-Olivo, G. and Heredia, J.B. (2018). Flavonoids and phenolic acids from oregano: Occurrence, biological activity and health benefits. Plants. 7(1): 2.

Koo, H., De Guzman, P.N., Schobel, B.D., Smith, A.V. and Bowen, W.H. (2006). Influence of cranberry juice on glucanmediated processes involved in Streptococcus mutans biofilm development. Caries Research. 40(1): 20-27.

Lahlah, Z.F., Meziani, M., Maza, A. (2012). Silymarin natural antimicrobial agent extracted from Silybum marianum. Journal of Academy. 2: 164-169.

Marri, V. and Richner, H. (2015). Immune response, oxidative stress and dietary antioxidants in great tit nestlings. Comparative Biochemistry and Physiology Part A: Molecular and Integrative Physiology. 179: 192-196.

Mazzola, P.G., Jozala, A.F., Moriel, P., Penna, T. (2009). Minimal inhibitory concentration (MIC) determination of disinfectant and/or sterilizing agents. Brazilian Journal of Pharmacological Sciences. 45: 241-248.

Nethathe, B.B. and Ndip, R.N. (2011). Bioactivity of Hydnoraafricana on selected bacterial pathogens: Preliminary phytochemical screening. African Journal of Microbiology Research. 5(18): 2820-2826.

Obeidat, M., Shatnawi, M., Al-alawi, M., Al-Zu'bi, E., Al-Dmoor, H., Al-Qudah M, El-Qudah, J. and Otri, I. (2012). Antimicrobial activity of crude extracts of some plant leaves. Research Journal of Microbiology. 7: 59-67.

Prusty, A.K. and Patro, S.K. (2014). Study of in vitro antibacterial activity of leave extract of Citrus maxima. Annals of Plant Sciences. 12(3): 899-904.

Pulipati, S., Babu, P.S., Naveena, U., Parveen, S.R., Nausheen, S.S. and Sai, M.T. (2017). Determination of total phenolic, tannin, flavonoid contents and evaluation of antioxidant property of Amaranthus tricolor (L). International Journal of Pharmacognosy and Phytochemical Research. 9(6): 814-819.

Rai, P.K. and Lalramnghinglova, H. (2010). Lesser known ethnomedicinal plants of Mizoram, North East India: An Indo-Burma hotspot region. Journal of Medicinal Plants Research. 4(13): 1301-1307.

Rajendran, N., Subramaniam, S., Christena, L.R., Muthuraman, M.S., Subramanian, N.S., Pemiah, B. and Sivasubramanian, A. (2016). Antimicrobial flavonoids isolated from Indian medicinal plant Scutellaria oblonga inhibit biofilms formed by common food pathogens. Natural Product Research. 30(17): 2002-2006.
Sànchez, E., Rivas, M.C., Castillo, S., Leos-Rivas, C., Garcia, B.L., Ortiz, M.D.M. (2016). Antibacterial and antibiofilm activity of methanolic plant extracts against noscomial microorganisms. Evidence Based Complementary and Alternative Medicine. 16: 8-11.

Sapkota, B., Prakash, C. and Jain, V. (2020). Preliminary phytochemical screening and quantitative analysis of Citrus maxima (Brum.) leaves extract. International Journal of Research in Pharmacology and Pharmacotherapeutics. 9(1): 100106.

Showmiya, K. and Ananthi, T. (2018). Phytochemical screening and FTIR analysis of Citrus maxima Linn. leaves. International Journal of Pharma Research and Health Sciences. 6(3): 2634-2637.

Singh, A. and Navneet (2017). Citrus maxima (Burm.) Merr. A Traditional Medicine: Its Antimicrobial Potential and Pharmacological Update for Commercial Exploitation in Herbal Drugs- A Review. International Journal of ChemTech Research. 10: 642-651.

Skogman, M.E., Kujala, J., Busygin, I., Leino, R., Vuorela, P.M. and Fallarero, A., (2012). Evaluation of antibacterial and antibiofilm activities of cinchona alkaloid derivatives against Staphylococcus aureus. Natural Product Communications. 7(9): 1934578-1200700917.

Susanti, D., Hasnah, M.S., Farediah, A., Rasadah, M.A., Norio, A. (2007). Antioxidant and cytotoxicity of flavonoids from the flowers of Melastoma malabathricum Letters in Food Chemistry. 103: 710-716.

Tsai, Y.C., Yu, M.L., El-Shazly, M., Beerhues, L., Cheng, Y.B., Chen, L.C., Hwang, T.L., Chen, H.F., Chung, Y.M., Hou, M.F. and Wu, Y.C. (2015). Alkaloids from Pandanus amaryllifolius: Isolation and their plausible biosynthetic formation. Journal of Natural Products. 78(10): 2346-2354.

Vimberg, V., Kuzma, M., Stodulkovaì, E., Novak, P., Bednaìrovaì, L., Sulc, M. and Gazak, R. (2015). Hydnocarpin-type Flavonolignans: semisynthesis and inhibitory effects on Staphylococcus aureus biofilm formation. Journal of Natural Products. 78(8): 2095-2103.

Wintola, O.A. and Afolayan, A.J. (2015). The antibacterial, phytochemicals and antioxidants evaluation of the root extracts of Hydnoraafricana Thunb. used as antidysentericin Eastern Cape Province, South Africa. BMC Complementary and Alternative Medicine. 15(1): 1-12. 